\title{
Nicotinic acetylcholine receptor a7 subunits with a C2 cytoplasmic loop yellow fluorescent protein insertion form functional receptors
}

\author{
Teresa A MURRAY ${ }^{1,2, *}$, Qiang LIU ${ }^{1}$, Paul WHITEAKER ${ }^{1}$, Jie WU ${ }^{1}$, Ronald J LUKAS ${ }^{1}$ \\ ${ }^{1}$ Barrow Neurological Institute, St Joseph's Hospital and Medical Center, 350 W Thomas Rd, Phoenix, AZ 85013, USA; ${ }^{2}$ Center for BioOptical Nanotech- \\ nology, Biodesign Institute at Arizona State University, PO Box 5201, Tempe, AZ 85287-5201, USA
}

\begin{abstract}
Aim: Several nicotinic acetylcholine receptor (nAChR) subunits have been engineered as fluorescent protein (FP) fusions and exploited to illuminate features of nAChRs. The aim of this work was to create a FP fusion in the nAChR a7 subunit without compromising formation of functional receptors.

Methods: A gene construct was generated to introduce yellow fluorescent protein (YFP), in frame, into the otherwise unaltered, large, second cytoplamsic loop between the third and fourth transmembrane domains of the mouse nAChR a7 subunit ( $(7 \mathrm{Y})$. SH-EP1 cells were transfected with mouse nAChR wild type $\alpha 7$ subunits ( $\alpha 7$ ) or with $\alpha 7 Y$ subunits, alone or with the chaperone protein, hRIC-3. Receptor function was assessed using whole-cell current recording. Receptor expression was measured with ${ }^{125} \mathrm{I}$-labeled a-bungarotoxin (I-Bgt) binding, laser scanning confocal microscopy, and total internal reflectance fluorescence (TIRF) microscopy.

Results: Whole-cell currents revealed that a7Y nAChRs and a7 nAChRs were functional with comparable $\mathrm{EC}_{50}$ values for the $\alpha 7 \mathrm{nAChR}$-selective agonist, choline, and $\mathrm{IC}_{50}$ values for the $\mathrm{a} 7 \mathrm{nAChR}$-selective antagonist, methyllycaconitine. I-Bgt binding was detected only after co-expression with hRIC-3. Confocal microscopy revealed that $\alpha 7 Y$ had primarily intracellular rather than surface expression. TIRF microscopy confirmed that little a7Y localized to the plasma membrane, typical of a7 nAChRs.

Conclusion: nAChRs composed as homooligomers of a7Y subunits containing cytoplasmic loop YFP have functional, ligand binding, and trafficking characteristics similar to those of $\alpha 7 \mathrm{nAChRs}$. $\alpha 7 \mathrm{Y}$ nAChRs may be used to elucidate properties of a7 nAChRs and to identify and develop novel probes for these receptors, perhaps in high-throughput fashion.
\end{abstract}

Keywords: nicotinic receptor; fluorescent protein; confocal microscopy; protein engineering; protein expression; receptor trafficking; RIC-3; electrophysiology; dose-response relationship; radiotoxin binding Acta Pharmacologica Sinica (2009) 30: 828-841; doi: 10.1038/aps.2009.78

\section{Introduction}

Green fluorescent protein, its homologs and paralogs, and its artificial, spectrally-shifted mutants (collectively termed FPs), when genetically fused to proteins of interest, allow new and powerful means for examining protein expression and interactions ${ }^{[1]}$. Fluorescently tagged protein expression levels, localization and trafficking can be monitored spatially and temporally. Properties such as subunit assembly and chaperone/accessory protein interactions can be assessed using proteins labeled with different FPs and techniques such as fluorescence resonance energy transfer

* Correspondence to Teresa A MURRAY, PhD.

E-mail biodesigner1@gmail.com

Received 2009-03-01 Accepted 2009-04-28 and colocalization ${ }^{[2,3]}$. However, whether it be an epitope tag or a FP, insertion of an extra sequence into a protein can affect target protein properties and function ${ }^{[2,4,5]}$. FPs are $\sim 27-\mathrm{kDa}$ proteins comprised of $\sim 239$ amino acids in a $\beta$-barrel conformation ${ }^{[2,6]}$. Optimal placement of the bulky, FP fusion tag is critical to minimize impairment of the native function of the protein. Potential effects range from incorrect folding, trafficking, and endocytosis of transmembrane membrane proteins to disruption of ligand binding and protein-protein interaction $\operatorname{sites}^{[2,7,8]}$.

To date, several types of nicotinic acetylcholine receptor (nAChR) subunits have been constructed with fluorescent protein fusions. These subunit-FP fusions have revealed much about nicotinic receptors, such as their subunit stoichiometry, changes in expression levels and location of 
subtypes in the brain ${ }^{[9,10]}$. Whereas tagging the extracellular region with an FP provides an accessible tag for FP-targeted antibody staining and for trafficking studies ${ }^{[1,12]}$, it has been reported to interfere with endocytosis ${ }^{[8]}$ and to modify receptor function ${ }^{[4]}$. Alternatively, placing the FP in an intracellular domain might obviate these concerns; however, inserting it in this location presents other challenges including interruption of trafficking domains and phosphorylation sites, which could disrupt function ${ }^{[7]}$. Fortunately, several fluorescently tagged Cys-loop receptor subunits have been made with the FP inserted into the second, large intracellular loop (C2) between the third (M3) and fourth (M4) transmembrane domains; and these assembled receptors appear fully functional by several criteria ${ }^{[9,10,13-15]}$. However this suite does not yet include a nAChR $\alpha 7$ subunit with a C2 FP fusion.

$\alpha 7 \mathrm{nAChRs}$, composed as homooligomers of $\alpha 7$ subunits, are expressed in the autonomic nervous system, and they are among the most abundant nAChR subtypes in the brain ${ }^{[16,17]}$. $\alpha 7 \mathrm{nAChRs}$ appear to be involved in a wide range of normal functions, including attention, cognitive processing, learning and memory, and neuroprotection ${ }^{[18,19]}$. Additionally, their involvement has been implicated in nicotine dependence and in several neuropsychiatric pathologies, including schizophrenia and Alzheimer's disease ${ }^{[20,21]}$. Nevertheless, the understanding remains incomplete about $\alpha 7 \mathrm{nAChRs}$ and all of their roles in health and disease.

We chose to introduce FPs into the otherwise intact and unmodified $\mathrm{C} 2$ domain of the mouse nAChR $\alpha 7$ subunit, where we postulated that the insert would have minimal, if any, impact on ligand binding and functional features of a7 nAChRs. We selected an approach involving heterologous expression of these fusion proteins composed of $\alpha 7 \mathrm{sub}-$ units to provide proof of principle and to allow assessment of the impact of FP introduction. We demonstrated that levels of expression and functional properties of $n A C h R$ composed of wild-type $\alpha 7$ subunits or of yellow FP-tagged ( $\alpha 7 \mathrm{Y})$ subunits are comparable, we exploited $\alpha 7 \mathrm{Y} \mathrm{nAChR}$ fluorescence to track receptor subcellular distribution, and we showed that both $\alpha 7 \mathrm{nAChR}$ and $\alpha 7 \mathrm{Y} \mathrm{nAChR}$ levels increased when co-expressed with the chaperone protein, hRIC-3. This fluorescent receptor was designed for and appears fit for uses that should provide greater insights into the structure, function and cell biology of $\alpha 7 \mathrm{nAChRs}$ relevant to their roles in nervous system function and disease.

\section{Materials and methods}

Cloning of mouse nAChR a7subunit cDNA Total
RNA from mouse brain (Applied Biosystems/Ambion, Austin, TX) was used to synthesize first-strand cDNA using the SuperScript III First-Strand Synthesis System for RT-PCR (Invitrogen Corp, Carlsbad, CA) according to the manufacturer's instructions. Briefly, $5 \mu \mathrm{L}$ of a stock solution of $1 \mu \mathrm{g} / \mu \mathrm{L}$ of total RNA from mouse brain, $1 \mu \mathrm{L}$ of $50 \mu \mathrm{mol} / \mathrm{L}$ oligo(dT), $1 \mu \mathrm{L}$ of $10 \mu \mathrm{mol} / \mathrm{L}$ dNTP mix and $3 \mu \mathrm{L}$ of DEPCtreated water were mixed, incubated at $65^{\circ} \mathrm{C}$ for $5 \mathrm{~min}$, and then chilled on ice for 1 minute. A cDNA synthesis mix was added, and it contained $2 \mu \mathrm{L}$ of $10 \times$ reverse transcriptase (RT) buffer, $4 \mu \mathrm{L}$ of $25 \mathrm{mmol} / \mathrm{L} \mathrm{MgCl}_{2}, 2 \mu \mathrm{L}$ of $0.1 \mathrm{~mol} / \mathrm{L}$ DTT, $1 \mu \mathrm{L}$ of RNaseOUT ${ }^{\mathrm{TM}}(40 \mathrm{U} / \mu \mathrm{L})$, and $1 \mu \mathrm{L}$ of Super$\mathrm{Script}^{\mathrm{TM}} \mathrm{III}(200 \mathrm{U} / \mu \mathrm{L})$. The solution was incubated at $50{ }^{\circ} \mathrm{C}$ for $50 \mathrm{~min}$, and then the reaction was terminated by heat inactivation at $85^{\circ} \mathrm{C}$ for $5 \mathrm{~min}$ followed by chilling on ice. After cooling, $1 \mu \mathrm{L}$ of $E$ coli RNase $\mathrm{H}(2 \mathrm{U} / \mu \mathrm{L})$ was added, and the solution was incubated at $37^{\circ} \mathrm{C}$ for $20 \mathrm{~min}$ then chilled on ice. Aliquots of cDNA stock solution $(0.1 \mu \mathrm{g} / \mu \mathrm{L})$ were prepared and stored at $-20^{\circ} \mathrm{C}$.

Primers for polymerase chain reaction (PCR) were designed to specifically amplify cDNA corresponding to the a7 gene, including parts of 5'- and 3'-, non-coding regions, and to insert flanking restriction enzyme (RE) sites with 4-base leader sequences to facilitate hybridization at the $\mathrm{RE}$ sites. The forward and reverse strand primer sequences were 5'-A TAT GGA TCC GGG ACA CGG CGG CTG CTC-3' and 5'-G CGC TCT AGA CTA AGA TCT ACC CTG TAG G-3', respectively. Primers were synthesized by Operon (Huntsville, AL). The RE sites underlined are for Bam HI and XbaI. The PCR reaction consisted of $22 \mu \mathrm{L}$ of PCR SuperMix High Fidelity polymerase mixture (Invitrogen Corp), $3 \mu \mathrm{L}(0.1 \mu \mathrm{g} / \mu \mathrm{L})$ of nAChR $\alpha 7$ subunit cDNA, and $3 \mu \mathrm{L}$ of each primer $(100 \mu \mathrm{mol} / \mathrm{L})$. Thirty-five cycles of PCR, $1 \mathrm{~min}$ at $95^{\circ} \mathrm{C}, 1 \mathrm{~min} 30 \mathrm{~s}$ at $55^{\circ} \mathrm{C}$ and $2 \min 30 \mathrm{~s}$ at $72{ }^{\circ} \mathrm{C}$, followed by a $4 \mathrm{~min}$ extension at $72{ }^{\circ} \mathrm{C}$, were performed using a Stratagene Robocycler (Stratagene, La Jolla, CA). A sample of the reaction was run on $0.8 \%$ agarose gel with ethidium bromide, allowing identification of a single product of the expected size of 2200 base-pairs. The remaining reaction was cleaned using a Wizard SV Gel and PCR Purification System (Promega, Madison, WI) according to the manufacturer's instructions.

Cleaned cDNA was immediately subcloned into pGEMT-Easy (Promega) in an overnight ligation at $14{ }^{\circ} \mathrm{C}$, and $5 \mu \mathrm{L}$ of the ligation product was used to transform competent, DH5 $\alpha$ bacteria. Colonies were selected using blue/white screening per manufacturer's directions and grown overnight in CIRCLEGROW ${ }^{\circledR}$ (MP Biomedicals, Solon, OH). Purified DNA was isolated using a Quantum Prep ${ }^{\circledR}$ miniprep kit 
(Bio-Rad Laboratories, Hercules, CA). DNA sequencing was performed on selected clones (University of Arizona DNA Sequencing Lab, Tucson, AZ; U of A) using primers to generate overlapping segments in both the forward and reverse directions.

Construction of fluorescently-labeled, $a 7$ subunitYFP fusion proteins ( $\mathbf{\alpha} 7 \mathbf{Y})$ Overlapping PCR was used with primers designed to insert a combined hemagglutinin (HA) and enhanced YFP tag, in frame, into the C2 loop of the mouse $\alpha 7$ subunit. The HA immunohistochemical tag had already been placed $5^{\prime}$ or $\mathrm{N}$-terminal to the gene for enhanced yellow $\mathrm{YFP}^{[9]}$. Three oligonucleotide segments were generated by separate PCR reactions, as follows: "A," encoding the mouse nAChR $\alpha 7$ subunit from part of the 5 '-flanking region through amino acid 412; "B," encoding the HA-YFP insert; and " $C$," encoding the $\alpha 7$ subunit from amino acid 413 through part of the 3'-flanking region. Segments A and $\mathrm{C}$ were created using the previously-generated, pGEMT-Easy- $\alpha 7$ plasmid as a template. A construct for the mouse nAChR $\alpha 4$ subunit gene containing the HA-YFP fusion protein, a kind gift from Dr Henry Lester ${ }^{[9]}$, served as the template DNA for B. For segment A, the forward primer was 5'-TAA TAC GAC TCA CTA TAG GG-3' which hybridized to the $\mathrm{T} 7$ promoter region of the pGEM-T-Easy- $\alpha 7$ vector; the reverse primer, 5'-TGG GAC GTC ATA AGG ATA GCA GGC CAA ACG ACC ACA-3' added an 18-base overlapping sequence for $B$ to nucleotides corresponding to the $3^{\prime}$ region of A. Similarly, for segment B, the forward primer, 5'-TGT GGT CGT TTG GCC TGC TAT CCT TAT GAC GTC CCA-3' added an 18-base sequence overlapping segment $A$. In the same manner, the reverse primer, 5'-CTC ATC ATG TGT TGG GGA CTT GTA CAG CTC GTC CAT-3' added a $3^{\prime}$ sequence of 18 bases overlapping C. Likewise, the segment $C$ forward primer, 5'-ATG GAC GAG CTG TAC AAG TCC CCA ACA CAT GAT GAG-3' contained an 18-base overlapping sequence for $B$; the reverse primer sequence was 5'-GAT TTA GGT GAC ACT ATA G-3' which hybridized to the SP6 region of the pGEM-T-Easy- $\alpha 7$ vector. Thirty-five cycles of PCR, $1 \mathrm{~min}$ at $95^{\circ} \mathrm{C}, 1 \mathrm{~min} 30 \mathrm{~s}$ at $55^{\circ} \mathrm{C}$ and $1 \mathrm{~min}$ $30 \mathrm{~s}$ at $72{ }^{\circ} \mathrm{C}$, followed by a $4 \mathrm{~min}$ extension at $72^{\circ} \mathrm{C}$ generated the three segments. Each segment was gel purified using the Wizard SV system described previously.

Overlapping PCR was used to join B and C with a 1:10 molar ratio of $\mathrm{B}: \mathrm{C}$. To create a $\mathrm{BC}$ template, 5 cycles of $1 \mathrm{~min}$ at $95^{\circ} \mathrm{C}, 1 \mathrm{~min} 30 \mathrm{~s}$ at $55^{\circ} \mathrm{C}$ and $2 \mathrm{~min}$ at $72^{\circ} \mathrm{C}$, were run with of $100 \mu \mathrm{L}$ of SuperMix High Fidelity, $20 \mathrm{ng}$ of B and $200 \mathrm{ng}$ of $\mathrm{C}$. After the 5 th cycle, the forward primer for $\mathrm{B}$ and the reverse primer for $\mathrm{C}$ were added ( $3 \mu \mathrm{L}$ each, $10 \mu \mathrm{mol} / \mathrm{L}$ ) and 30 additional cycles were run, followed by a 4 min extension at $72{ }^{\circ} \mathrm{C}$. In like manner, A was joined to (BC) using the previous procedure, with an $\mathrm{A}$ :(BC) mass ratio of 1:10. The extension time was lengthened to $3 \mathrm{~min}$; $50 \mu$ Lof SuperMix and $1 \mu \mathrm{L}$ each of the A forward and C reverse primers were used. Gel purification, as previously described, was performed after each overlapping PCR step. The final PCR product was subcloned into PGEM-T-Easy and sequenced, ( $\mathrm{U}$ of $\mathrm{A}$ ).

Subcloning genes into mammalian expression vectors After sequence verification, both the wild type nAChR $\alpha 7$ subunit gene and the $\alpha 7 \mathrm{Y}$ gene construct were released from the cloning vector by digestion with $\mathrm{BamHI}$ and $\mathrm{Xba \textrm {I }}$ and subcloned into a mammalian expression vector, $\mathrm{pcDNA3.1^{+ }}$ with a hygromycin resistance gene (Invitrogen Corp). Proper insertion was confirmed using restriction digests.

Cell culture SH-EP1 cells were used to stably and heterologously express $\alpha 7 \mathrm{Y}$. SH-EP1 cells are an epitheliallike cell line subcloned from the SK-H-SK neuroblastoma line ${ }^{[22,23]}$; they are native nAChR-null and have served as a heterologous expression system for nicotinic receptors ${ }^{[24]}$. Cells were maintained in $100-\mathrm{mm}$ diameter, tissue culturetreated, polystyrene dishes at $37^{\circ} \mathrm{C}$ in a humidified atmosphere supplemented with $5 \% \mathrm{CO}_{2}$. Culture medium was completed DMEM (C-DMEM) consisting of Dulbecco's modified Eagle's medium (DMEM) with high glucose and buffered with bicarbonate supplemented with fetal bovine serum (FBS; $5 \%)$, inactivated horse serum $(10 \%)$, sodium pyruvate $(1 \mathrm{mmol} / \mathrm{L}), \mathrm{L}$-glutamine $(8 \mathrm{mmol} / \mathrm{L})$, streptomy$\operatorname{cin}(100 \mu \mathrm{g} / \mathrm{mL})$ and penicillin $(100 \mathrm{U} / \mathrm{mL})$.

Creation of stably transfected cell line expressing $\alpha 7 \mathrm{Y}$ Transfections to create the stably transfected cell line were done using $1 \mu \mathrm{g}$ of $\alpha 7 \mathrm{Y}$ cDNA construct, linearized with SspI, and Effectene transfection reagent (Qiagen, Valencia, CA). Reagent components and DNA were mixed according to the manufacturer's instructions and incubated at room temperature for $5 \mathrm{~min}$. Cells between $70 \%-90 \%$ of confluence were released from the culture dish using Cell Stripper (Mediatech Corp, Manassas, VA) and resuspended in $10 \mathrm{~mL}$ of C-DMEM; the transfection solution was added, and the culture dish was incubated overnight under the conditions described above before culture medium was exchanged for fresh C-DMEM. Forty-eight hours post transfection, cells were trypsinized, resuspended in $2 \mathrm{~mL}$ of cell culture medium and seeded at low densities, from 1:100 to 1:1500 $(v / v)$, in C-DMEM containing hygromycin B $(130 \mathrm{mg} / \mathrm{mL}$; Calbiochem, San Diego, CA). After 1-2 weeks, colonies were picked using cloning disks soaked in trypsin (0.5\%)-EDTA $(0.2 \%)$ solution; disks were transferred to individual chambers in 24-well plates. Epifluorescence microscopy was 
employed 1-2 weeks later to screen surviving colonies for fluorescence. Cells that contained regions of bright, saturating fluorescence tended to rapidly loose expression of $\alpha 7 \mathrm{Y}$ after a few passages. Several clones were maintained for 6 or more passages; those that maintained a consistent level of fluorescence, without containing large regions of bright, saturating fluorescence, were selected for further propagation and cryopreservation. For cryopreservation, a confluent dish of cells was trypsinized and resuspended in $2 \mathrm{~mL}$ of C-DMEM. One $\mathrm{mL}$ aliquots were transferred to cryopreservation vials then prepared for freezing by adding $10 \%$ dimethyl sulfoxide and $10 \%$ additional FBS. Vials were placed in an isopropanol freezing container stored overnight at $-80^{\circ} \mathrm{C}$ to control the rate of freezing before vials were transferred to liquid nitrogen storage or $-80^{\circ} \mathrm{C}$ storage.

Transient transfections Transient transfections were performed with either Lipofectamine ${ }^{\mathrm{TM}} 2000$ (Invitrogen Corp; used for cells subjected to patch-clamp recording) or ExpressFect ${ }^{\mathrm{TM}}$ (Denville Scientific Inc, Metuchen, NJ; used for cells subjected to radioligand binding assays or to confocal or TIRF microscopy) according to the producers' instructions, with one exception. For ExpressFect ${ }^{\mathrm{TM}}$, it was determined that a 3-h incubation time with the transfection reagent was sufficient for optimal transfection efficiency and improved cell viability. Additionally, media without antibiotics were used after transfection reagent solutions were removed. Transfection solutions were prepared in batches, and aliquots were used to ensure consistent application of reagents across samples. Sham transfections were performed for both TE671/RD and untransfected SH-EP1 cell types; no disruption of cell growth or cell death was apparent. Human pcDNA3-neo-human ric-3 (hric-3) was a kind gift of Dr Millet Treinin (Hebrew University) ${ }^{[25]}$ through Dr William Green (University of Chicago). Hosts for transient transfections were either wild-type SH-EP1 cells (exposed to $105 \mathrm{ng}$ of $\mathrm{nAChR}$ a7 subunit cDNA alone or along with $63 \mathrm{ng}$ of hric-3 cDNA per well per well in 24-well trays) or SH-EP1 cells already stably expressing $a 7 \mathrm{Y}$ (exposed to vehicle alone or to $63 \mathrm{ng}$ of hric-3 cDNA per well.

For confocal and TIRF experiments, selected dishes of cells were also transiently transfected with pCS2-mCherry (300 ng per 35-mm dish), to express a red fluorescent protein (pmCherry FP), which is targeted to the plasma membrane. The construct contains two copies of a myristoylation signal sequence subcloned from the Lyn Kinase gene. The signal sequence is immediately upstream of the FP gene and targets the FP to the plasma membrane. It was a kind gift of $\mathrm{Dr}$ Sean Megason (California Institute of Technology) ${ }^{[26]}$. Cells requiring transient transfections were seeded a day prior to transfection and used for experiments within 16 to $48 \mathrm{~h}$ of transfection.

Culture dishes for electrophysiology and microscopy For confocal and TIRF microscopy, cells were seeded onto 35-mm diameter culture dishes with a № 1.5 cover slip glass bottom coated with poly-D-lysine (MatTek Corp, Ashland, MA). Cells imaged with epifluorescence microscopy were typically seeded in 24-well plates or in 100 -mm tissue culture treated polystyrene dishes. For whole-cell patch clamp experiments, cells were seeded onto $35-\mathrm{mm}$ tissue culture treated polystyrene dishes.

Epifluorescence microscopy An Olympus IX70 epifluorescence microscope with a $20 \times 0.70$ NA UPlanApo objective, a MicroFire digital camera (Olympus America, Inc, Center Valley, PA) and an enhanced YFP filter cube (Leeds Precision Instruments Inc, Minneapolis, MN) were used to screen clones for expression and to compare the degree of expression of $\alpha 7 \mathrm{Y} \mathrm{nAChR}$ between clonal colonies. Images were captured using Magnafire 2.1 software (Media Cybernetics, Carlsbad, CA).

Laser scanning confocal microscopy (LSCM) A Nikon C1 laser scanning confocal microscope (Nikon Instruments Inc, Melville, NY) with a spectral imaging system and a Nikon PlanApo 60x/1.40 NA oil objective was used to image cells containing fluorescently-tagged proteins. YFP was excited using the 514.5-nm line of an argon laser; and Cherry FP was excited using a 561-nm solid state laser. Emission spectra, or $\lambda$ stacks, were acquired at $5 \mathrm{~nm}$ resolution between 520-600 nm, except for images of Cherry FP which were observed using a range of 525-675 nm. All images were acquired using the settings, as follows: $512 \times 512$ pixels, $6.72 \mu$ s pixel dwell time, 12-bit intensity resolution, $60 \mu \mathrm{m}$ pinhole diameter, 200 spectral gain, $5 \mathrm{~nm}$ spectral imaging bandwidth, and an average of 4 scans per image.

Each pixel in the spectral image contained the fluorescence intensity over the entire range. The linear unmixing algorithm of the Nikon EZ-C1 Viewer (Nikon Instruments Inc) was used, offline, to separate the overlapping spectra of YFP and Cherry FP, as well as to remove autofluorescence. Singly transfected SH-EP1 cells were used to acquire reference spectra.

Total internal reflection fluorescence microscopy Cellular autofluorescence was minimized by imaging in extracellular imaging solution consisting of $10 \mathrm{mmol} / \mathrm{L}$ HEPES, $4 \mathrm{mmol} / \mathrm{L} \mathrm{KCl}, 150 \mathrm{mmol} / \mathrm{L} \mathrm{NaCl}, 2 \mathrm{mmol} / \mathrm{L}$ $\mathrm{CaCl}_{2}, 2 \mathrm{mmol} / \mathrm{L} \mathrm{MgCl}_{2}$, and $10 \mathrm{mmol} / \mathrm{L}$ glucose. Transiently transfected cells were imaged 18-48 $\mathrm{h}$ after transfection; stably transfected cells were imaged $\sim 24 \mathrm{~h}$ after seeding. An Olympus IX71 inverted microscope with a PlanApo 
100x/1.45 NA oil objective (Olympus America, Inc) and an Olympus TIRF illuminator were used for imaging. An Andor Laser Combiner (ALC; Andor, Belfast, Ireland) equipped with an acoustic-optical tunable filter was used to control the excitation laser excitation wavelength and intensity. Its $25 \mathrm{~mW}$ diode pumped solid state 561-nm laser was used to excite pmCherry, a red FP. An external Melles-Griot Ar ion laser (Melles-Griot, Carlsbad, CA) was coupled to the ALC via a fiber optic cable. Its 488-nm laser line was used to excite YFP. The Optosplit Emission GFP/RFP filter set (GFP: 525/30, DM 555, RFP: 598/40) and the microscope filter cube with dichroic (FF505/606-Di01-25×36) were from Semrock (Semrock, Rochester, NY). A Photometrics Cascade 650 charge-coupled device camera with 16-bit resolution (Princeton Instruments, Trenton, NJ) and an Andor IQ image capture and analysis software program (Andor Technology PLC, Belfast, Ireland) were used to capture images using a $300 \mathrm{~ms}$ integration time ${ }^{[10,15]}$. Colocalization of pmCherry and YFP images was visualized using Image J software with the colocalization finder plug-in ${ }^{[52]}$.

Patch-clamp whole-cell current recordings Conventional whole-cell current recording, coupled with computercontrolled two-barrel fast application and removal of agonists was used in this study, as previously described ${ }^{[27]}$. Briefly, cells plated on $35-\mathrm{mm}$ tissue culture treated polystyrene dishes were placed on the stage of an Olympus IX70 inverted microscope (Olympus America, Inc) and continuously superfused with standard external solution $(2 \mathrm{~mL} / \mathrm{min})$. The standard external solution contained (in mmol/L) $120 \mathrm{NaCl}$, $3 \mathrm{KCl}, 2 \mathrm{MgCl}_{2}, 2 \mathrm{CaCl}_{2}, 25 \mathrm{D}$-glucose, and 10 HEPES, and was adjusted to $\mathrm{pH} 7.4$ with Tris-base. Tris ${ }^{+}$electrodes were filled with solution containing (in mmol/L) 110 Tris phosphate dibasic, 28 Tris-base, 11 EGTA, $2 \mathrm{MgCl}_{2}, 0.1 \mathrm{CaCl}_{2}$, and $4 \mathrm{Mg}$-ATP; $\mathrm{pH}$ 7.3. Glass microelectrodes, with 3-5 M 2 resistance between the pipette and extracellular solutions were used to form tight seals ( $>1 \mathrm{G} \Omega$ ) on the cell surface, continued suction was applied to convert to conventional whole-cell recording. The cells were voltage-clamped at holding potentials of $-60 \mathrm{mV}$, and ion currents in response to application of ligands were measured with an Axon 200B amplifier (Axon Instruments, Foster City, CA). Whole-cell access resistance was less than $20 \mathrm{M} \Omega$ before series resistance compensation. Both pipette and whole-cell current capacitances were minimized, and series resistance was routinely compensated to $80 \%$.

Data were acquired at $10 \mathrm{kHz}$, filtered at $2 \mathrm{kHz}$, displayed and digitized online with a Digidata 1322 series A/D board (Axon Instruments) and stored to a hard drive. Data acquisition of whole-cell currents was done using Clampex 9.2
(Axon Instruments), and the results were plotted using Prism 3.0 (GraphPad Software, San Diego, CA). nAChR acute desensitization (the decline in inward current amplitude over the course of agonist application) was analyzed for decay half-time ( $\mathrm{t}=0.693 / \mathrm{k}$ for decay rate constant $\mathrm{k})$, peak current $\left(I_{\mathrm{p}}\right)$, and steady-state current $\left(I_{\mathrm{s}}\right)$, using fits to the mono (or double) exponential expression $I=\left(\left[I_{\mathrm{p}}-I_{\mathrm{s}}\right] \mathrm{e}^{-k t}\right)+I_{\mathrm{s}}$ (or $I=\left(\left[I_{\mathrm{p}}\right.\right.$ $\left.\left.\left.-I_{\mathrm{i}}\right] \mathrm{e}^{-k l t}\right)+\left(\left[I_{\mathrm{i}}-I_{\mathrm{s}}\right] \mathrm{e}^{-k 2 t}\right)+I_{\mathrm{s}}\right)$, where $I_{\mathrm{i}}$ is the intermediate level of current and $\mathrm{k}_{1}$ and $\mathrm{k}_{2}$ are rate constants for the 2 separate decay processes. Curve fitting was performed using data between $10 \%$ and $90 \%$ of the difference between peak and steady-state currents. Concentration response profiles were fit to the Hill equation and analyzed using Origin 5.0. Comparisons of treatments were analyzed for statistical significance using $t$-tests. Prism 3.0 was used for graphic presentation of the experimental data for $\mathrm{EC}_{50}$ and $\mathrm{IC}_{50}$, presented as mean log molartstandard error of the mean (SEM), and in the narrative as mean molar values, including $95 \%$ confidence intervals. All experiments were performed at room temperature $\left(22 \pm 1{ }^{\circ} \mathrm{C}\right)$.

Radiotoxin binding assays of $\mathbf{n A C h R}$ surface expression Cells were seeded in 24-well tissue culture plates to approximately $80 \%$ of confluence two days prior to measurement. Any transfections were performed $24 \mathrm{~h}$ prior to binding assays as described above when cells were up to $100 \%$ confluent $\left(10^{5}\right.$ cells/well). Human TE671/RD cells, which express muscle-type $\mathrm{nAChRs}{ }^{[28]}$, served as a positive control for toxin binding assays, while untransfected SH-EP1 cells served as a negative control. Cells expressing human $\alpha 7$ (ha7) nAChRs were used as a positive control for hRIC-3 expression studies conducted using cells also transfected with hric-3 cDNA.

Total or non-specific I-Bgt binding to surface receptors was measured in triplicate for each condition per in situ assay; two assays were performed on different days. Culture medium was aspirated and replaced with $0.5 \mathrm{~mL}$ per well of Dulbecco's phosphate buffered saline (DPBS)+BSA $(0.1 \%$ $w / v)$ containing $2 \mathrm{nmol} / \mathrm{L}\left[{ }^{125} \mathrm{I}\right] \alpha-B g t\left(2000 \mathrm{Ci} \mathrm{mmol}^{-1}\right.$; Perkin Elmer Life Sciences), either alone (to define total binding) or in the presence of $1 \mu \mathrm{mol} / \mathrm{L} \alpha$-cobratoxin (to define non-specific binding). Reactions were incubated for 4 hours at room temperature followed by four 5-min washes with room temperature DPBS of successively increasing volume (0.2, $0.3,0.4$, and $0.5 \mathrm{~mL}$ per well). After washing, the cells were solubilized with $0.5 \mathrm{~mL}$ per well of $0.01 \mathrm{~mol} / \mathrm{L}$ $\mathrm{NaOH}+0.1 \%$ SDS. The well contents were aspirated into individual liquid scintillation tubes, mixed with $10 \mathrm{~mL}$ of UniverSol scintillation fluid (MP Biomedicals, Irvine, CA), and incubated overnight at room temperature. Retained 
$\left[{ }^{125} \mathrm{I}\right]$ was counted using a Packard TriCarb liquid scintillation analyzer (60\% counter efficiency; Packard Instrument Co, Meriden, CT). For each transfection condition, mean non-specific binding (in the presence of unlabeled cobratoxin) was subtracted from the respective total binding values, giving specific cell-surface labeling. Data were converted to molecules of specifically bound I-Bgt per cell to allow comparison of surface expression levels across conditions.

Data analysis Summary data are reported as the mean \pm standard deviation (SD), or as noted, the mean \pm (SEM). Pairwise $t$-tests were used to compare means using the assumption of normality and equal variance; significance was established where $P<0.05$.

\section{Results}

a7Y construct design and creation Sequences encoding a YFP epitope tagged-FP were inserted, in frame, into a cDNA construct encoding the mouse nAChR $\alpha 7$ subunit. The fusion protein was designed to include an HA-YFP polypeptide in the $\mathrm{C} 2$ domain of the $\alpha 7$ subunit (Figure 1A), between the third (M3) and fourth (M4) transmembrane domains, without removing any of the native $\alpha 7$ subunit amino acids in this region (Figure 1B). DNA sequencing confirmed the proper orientation and sequence of the mouse gene and HA-YFP fusion. When assembled, the $\alpha 7 \mathrm{Y}$ receptor will have five fluorescently-labeled subunits.

Insertion of YFP into the mouse $\alpha 7$ subunit between C412 and S413 avoided the putative ER retention site R446, F447, R448 ${ }^{[29]}$, avoided all but one of the predicted tyrosine, serine and threonine phosphorylation sites ${ }^{[30]}$, preserved all of the negatively charged residues, which may be important for avoiding outward conductance of intracellular anions, left residues near the transmembrane region intact ${ }^{[7]}$, and as well as a dendritic localization site between residues G349$\mathrm{M} 395^{[11]}$. It also left a 20-residue buffer between the FP and the most proximal residue involved in hRIC- 3 interaction, L433, which is in the $\alpha 7$ putative amphipathic helix, D432 through C449, near $\mathrm{M}^{[29]}$.

Whole-cell patch clamp shows a7Y nAChRs have function Initial whole-cell recording using $10 \mathrm{mmol} / \mathrm{L}$ choline as an agonist produced similar currents in cells stably expressing $\alpha 7 \mathrm{Y}$ (Figure $2 \mathrm{~A}$ ) as those transiently transfected with wild type $\alpha 7$ (Figure 2B). For both constructs, activation and desensitization of inward currents were extremely rapid, as is characteristic for $\alpha 7 \mathrm{nAChR}$ functional responses $^{[31]}$. Cells expressing $\alpha 7$ had a mean $( \pm$ SEM $)$ peak current of $193 \pm 28 \mathrm{pA}$, and cells expressing $\alpha 7 \mathrm{Y}$ had a mean peak response of $180 \pm 21 \mathrm{pA}$ ( $n=6$ cells each; $P=0.70)$. Even
A

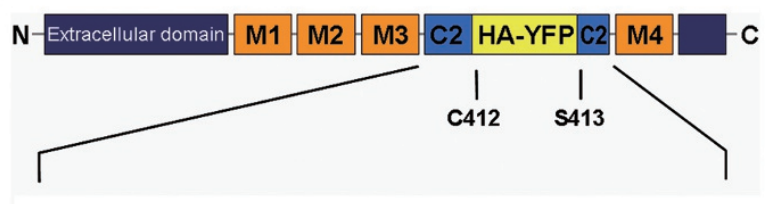

B

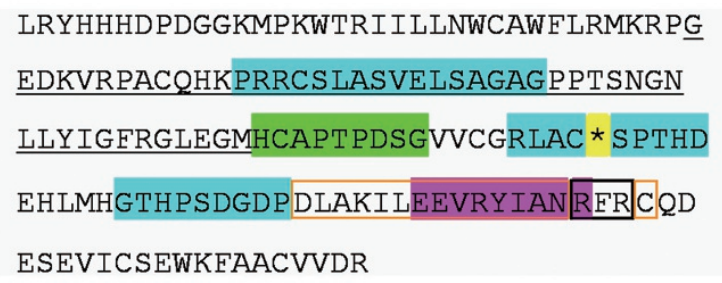

Figure 1. Design of mouse $\alpha 7 \mathrm{nAChR}$ subunit with HA-YFP insertion $(\alpha 7 Y)$. Schematic illustration of the design of the fluorescently tagged mouse $\alpha 7 \mathrm{nAChR}$ subunit involving insertion of the gene for enhanced yellow fluorescent protein (YFP) immediately downstream of the hemagglutinin (HA) epitope tag. HA-YFP was genetically inserted between C412 and S413 in the second, large cytoplasmic loop (C2) between the third (M3) and fourth (M4) transmembrane domains of the $\alpha 7$ subunit. Functional motifs in the $\alpha 7$ subunit C2 loop are noted in the amino acid sequence printed beneath the diagram. Underlined resides are the dendritic targeting signal 349-GEDKVRPACQHKPRRCSLASVELSAGAGPPTSNGNLLYIGFRGLEGM$395^{[11]}$. Also indicated are predicted phosphorylation sites for serine (light blue) 361-PRRCSLASV-369, 364-CSLASVELS-372, 368-SVELSAGAG-376, 409-RLACSPTHD-417, 423-GTHPSDGDP-341; threonine (bright green), 396-HCAPTPDSG-404; and tyrosine (pink), 438-EEVRYIANR-446 ${ }^{[30]}$; a putative ER retention signal(black box) 446-RFR-448 ${ }^{[29]}$; and a putative amphipathic helix, D432-C449 (orange box), including L433 shown to interact with hRIC- $3^{[29]}$. The asterisk denotes the location of the HA-YFP gene insertion.
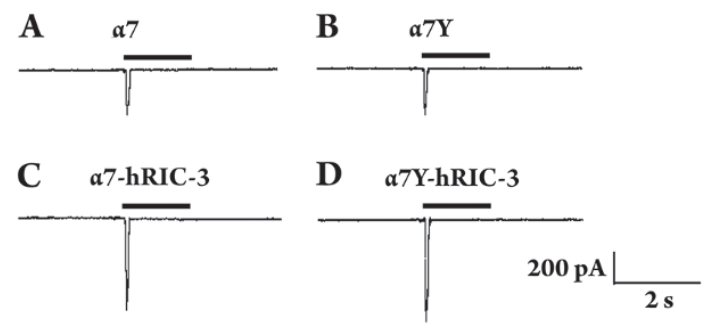

Figure 2. Functional responses to a nicotinic agonist in cells expressing $\alpha 7 \mathrm{nAChRs}$ or $\alpha 7 \mathrm{Y}$ nAChRs. Representative patch clamp wholecell current response traces during application of $10 \mathrm{mmol} / \mathrm{L}$ choline to cells transfected with $\alpha 7$ (A) or $\alpha 7 \mathrm{Y}$ (B) or co-transfected with $\alpha 7$ and hRIC-3 (C) or $\alpha 7 \mathrm{Y}$ and hRIC-3 (D). Mean ( \pm SEM) peak currents for $\alpha 7 \mathrm{nAChRs}$ or $\alpha 7 \mathrm{Y}$ nAChRs were $193 \pm 28 \mathrm{pA}$ or $180 \pm 21 \mathrm{pA}$, respectively. Cells transfected with $\alpha 7$ or $\alpha 7 \mathrm{Y}$, each co-expressed with hRIC-3, produced mean $( \pm$ SEM) peak currents of $514 \pm 59$ and $554 \pm 40$ $\mathrm{pA}$, respectively, which were more than double $(n=6$ each; $P<0.001)$ peak current amplitudes elicited in cells without hRIC-3. 
though means for transfection were different for these cells, peak current levels were similar. Transient co-transfection of SH-EP1 cells with $\alpha 7$ and hric-3 cDNA yielded cells exhibiting an over two-fold increase in current $(514 \pm 59 \mathrm{pA}$; Figure $2 \mathrm{C})$ relative to cells expressing $\alpha 7$ alone $(P<0.001)$. Likewise, for cells expressing $\alpha 7 \mathrm{Y}$ (Figure $2 \mathrm{D}$ ), the mean current doubled to $554 \pm 40$ pA when hRIC-3 was also expressed $(P<$ $0.001)$.

Concentration dependencies for peak whole-cell currents responses to the $\alpha 7 \mathrm{nAChR}$-selective agonist, choline, acting at cells expressing $\alpha 7 \mathrm{Y}$ or wild-type $\alpha 7$ subunits were comparable, as the two curves nearly overlay (Figure $3 \mathrm{~A})$. The effective concentration to elicit a $50 \%$ response, $\mathrm{EC}_{50}$, was nearly identical for both, being 2.61 (1.05-6.50) $\mathrm{mmol} / \mathrm{L}$ for $\alpha 7$ cells and $3.00(1.82-4.92) \mathrm{mmol} / \mathrm{L}$ for $\alpha 7 \mathrm{Y}$ cells (mean molar (95\% confidence interval); $n=6$ cells each). Hill coefficients for one-site fits to the logistic equa-

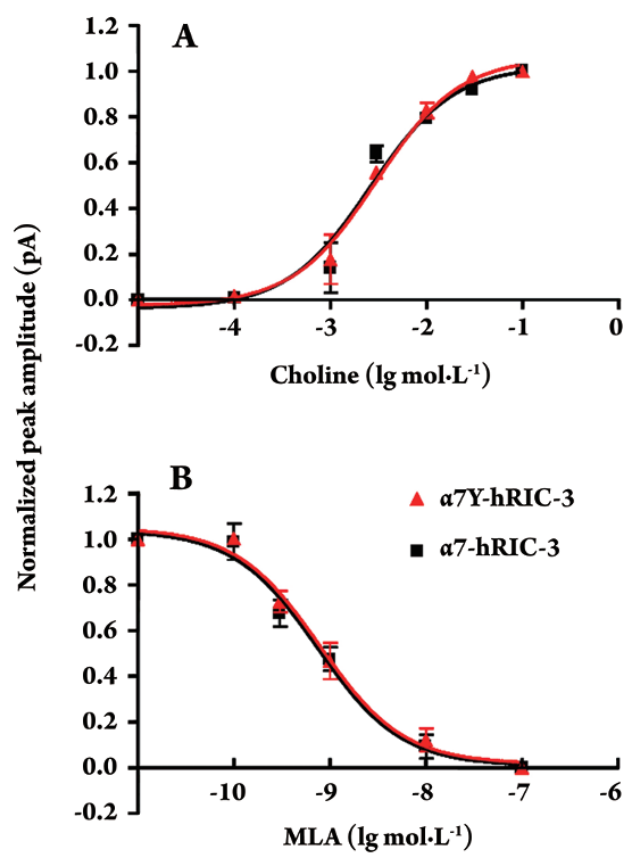

Figure 3. Concentration-response curves for choline and MLA. Normalized whole-cell peak currents ( $y$-axis, $p A$ ) were determined at the indicated drug concentrations ( $\mathrm{x}$-axis, log molar) for SH-EP1 cells expressing $\alpha 7$ or $\alpha 7 \mathrm{Y}$, each co-transfected with hRIC-3. (A) Choline concentration-response curves were nearly identical $(P>0.05)$, yielding $\mathrm{EC}_{50}$ values (mean \pm SEM) for $\alpha 7 \mathrm{nAChRs}$ of $-2.58 \pm 0.14$ and for $\alpha 7 \mathrm{Y}$ $n A C h R s$ of $-2.52 \pm 0.08$ ( $n=6$ cells for each.). (B) MLA concentrationresponse curves were obtained after a 2 -min preincubation with MLA and continuing exposure to the antagonist in the presence of $10 \mathrm{mmol} / \mathrm{L}$ choline. Again, both response curves were virtually identical $(\mathrm{P}>0.05)$, yielding $\mathrm{IC}_{50}$ values $( \pm$ SEM $)$ for $\alpha 7 \mathrm{nAChRs}$ of $-9.13 \pm 0.12$ and for $\alpha 7 \mathrm{Y} n A C h R s$ of $-9.10 \pm 0.11$ ( $n=6$ cells for each). tion were $1.31 \pm 0.35$ and $1.38 \pm 0.12$ for $\alpha 7$ and $\alpha 7 \mathrm{Y}$, respectively. Additionally, concentration profiles for the inhibition of the response to $10 \mathrm{mmol} / \mathrm{L}$ choline (a concentration that elicits $90 \%$ of the peak current) after a 2 -min incubation in the presence of the $\alpha 7 \mathrm{nAChR}$-selective antagonist, methyllycaconitine (MLA), were virtually identical for both cell types (Figure 3B). The $\mathrm{IC}_{50}$ for MLA was $0.75(0.32-1.78)$ and $0.79(0.36-1.73) \mathrm{nmol} / \mathrm{L}$ for cells expressing $\alpha 7$ and $\alpha 7 \mathrm{Y}$, respectively (mean molar (95\% confidence interval) $n=6$ cells for each). Hill coefficients were $-0.99 \pm 0.32$ for a $7 \mathrm{nAChRs}$ and $-1.06 \pm 0.32$ for $\alpha 7 \mathrm{Y}$ nAChRs. Thus, both agonist and antagonist responses for $\alpha 7 \mathrm{Y} n A C h R s$ strongly resembled those obtained for $\alpha 7 \mathrm{nAChRs}$.

Radioligand binding confirms $\alpha 7 \mathrm{Y}$ surface expression In situ radioligand binding assays using I-Bgt were performed to determine if $\alpha 7 \mathrm{Y} n A C h R s$ can bind Bgt, which is known to bind wild type $\alpha 7 \mathrm{nAChRs,} \mathrm{to} \mathrm{assess} \mathrm{levels} \mathrm{of} \mathrm{receptor}$ expression on the cell surface, and to ascertain effects of coexpression of hRIC-3. Additional studies were done using an established cell line ${ }^{[51]}$ stably and abundantly expressing nonfluorescent $\mathrm{h} \alpha 7 \mathrm{nAChRs}$ as a positive control. In the absence of hRIC-3, cells transiently expressing $\alpha 7$ or stably expressing $\alpha 7 Y$ did not show cell surface binding for I-Bgt above non-specific binding levels (data not shown, but $P>0.05$ ). However, transient transfection with hric-3 cDNA increased specific I-Bgt binding well above non-specific levels in two separate experiments for both cell types $(3279 \pm 243$ and $317 \pm 46$ sites per $\alpha 7 \mathrm{Y}$ cell; $2532 \pm 304$ and $4538 \pm 473$ for sites per $\alpha 7$ cell; compared to $14653 \pm 2618$ and $6693 \pm 1324$ sites per cell for the control, the stably expressed, ha7 cell line; Figure 4).

a $7 \mathrm{Y}$ protein and/or $\alpha 7 \mathrm{Y}$ nAChR are predominately found in intracellular pools SH-EP1 cells stably expressing $\alpha 7 \mathrm{Y}$ were transiently transfected with pmCherry, a red fluorescent protein that inserts into and conveniently identifies the plasma membrane (Figure 5A). Another set of cells was transfected to express both pmCherry and hRIC-3 (Figure 5C). Cells were visualized using LSCM z-stacks (a set of optical slices at progressively higher $\mathrm{z}$ positions through a cell) to localize pmCherry (red) and $\alpha 7 \mathrm{Y}$ (green) signals. Each of the representative images is from a set of confocal optical slices. pmCherry-derived fluorescence was excluded from intracellular regions as well as nuclei, but it was evident in well-defined borders around cells and also intensely labeled filopodia. Conversely, $\alpha 7 \mathrm{Y}$-derived fluorescence filled much of the intracellular space in a lattice-like pattern and was excluded from cell nuclei (large dark areas in each image). Furthermore, it had some localization in or near plasma membrane regions as identified by pmCherry FP. 


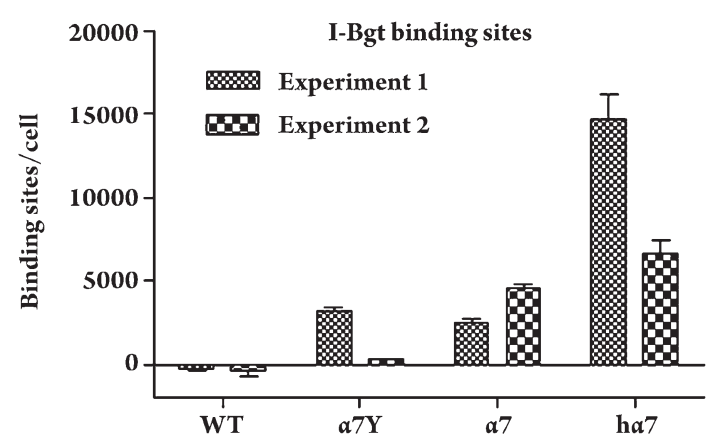

Figure 4. I-Bgt binding to cell surface receptors. I-Bgt, a radiolabeled neurotoxin with high affinity for $\alpha 7 \mathrm{nAChR}$, was incubated $(2 \mathrm{nmol} / \mathrm{L}$ final concentration) with cells expressing $\alpha 7, \alpha 7 \mathrm{Y}$ alone (data not shown) or along with co-transfected hRIC-3, with a control cell line stably expressing human $\alpha 7 \mathrm{nAChRs,}$ or with untransfected SH-EP1 cells. Non-specific binding was assessed in the presence of a 500-fold excess of unlabeled cobratoxin, and specific binding levels [y-axis, mean $( \pm \mathrm{SD})$ number of binding sites per cell (triplicate determinations each in two separate experiments, 1 - gray bars; 2 - checkered bars)] were determined. Untransfected SH-EP1 cells are native nAChR-null and showed a statistically insignificant level of specific I-Bgt binding, as did cells expressing only $\alpha 7$ or $\alpha 7 \mathrm{Y}$ (not shown). However, specific binding was seen for cells expressing $\alpha 7 \mathrm{nAChRs}, \alpha 7 \mathrm{Y}$ nAChRs, or for the positive control cell line along with hRIC-3 .

Intracellular compartments, such as the endoplasmic reticulum (ER), can be located close to the plasma membrane. Furthermore, confocal microscopy images of the plasma membrane may contain underlying intracellular regions which can include the ER. Considering this, we decided to use filopodia, excluding the region proximal to the cell body, as unambiguous regions of plasma membrane since they do not contain $\mathrm{ER}^{[32]}$. All cells in which filopodia were visible ( $n=10$ cells) had $\alpha 7$ Y-derived fluorescence in some of these processes (Figure 5B, 5D), demonstrating that a $7 \mathrm{Y}$ was expressed in the plasma membrane.

TIRF microscopy detects surface expression of $\mathfrak{\alpha} 7 \mathrm{Y}$ Total internal reflectance fluorescence (TIRF) microscopy was used to image cellular regions within $100 \mathrm{~nm}$ above the cover slip to determine if $\alpha 7 \mathrm{Y}$ was trafficked to the plasma membrane. Cells stably expressing $\alpha 7 \mathrm{Y}$ were transiently transfected with pmCherry to allow identification of the plasma membrane. Fluorescence derived from $\alpha 7 \mathrm{Y}$ and pmCherry was observed in the membrane region around the cell body and also in micropodia ${ }^{[12]}$, which are fine filopodial processes extending from the cell body. Whereas micropodia were brightly fluorescent for pmCherry, only about $15 \%$ of the cells imaged had $\alpha 7 \mathrm{Y}$ in these regions ( $n=71$ cells) with no difference between cells expressing hRIC-3 (15.4\%) and those not expressing the chaperone (15.7\%). A rep-
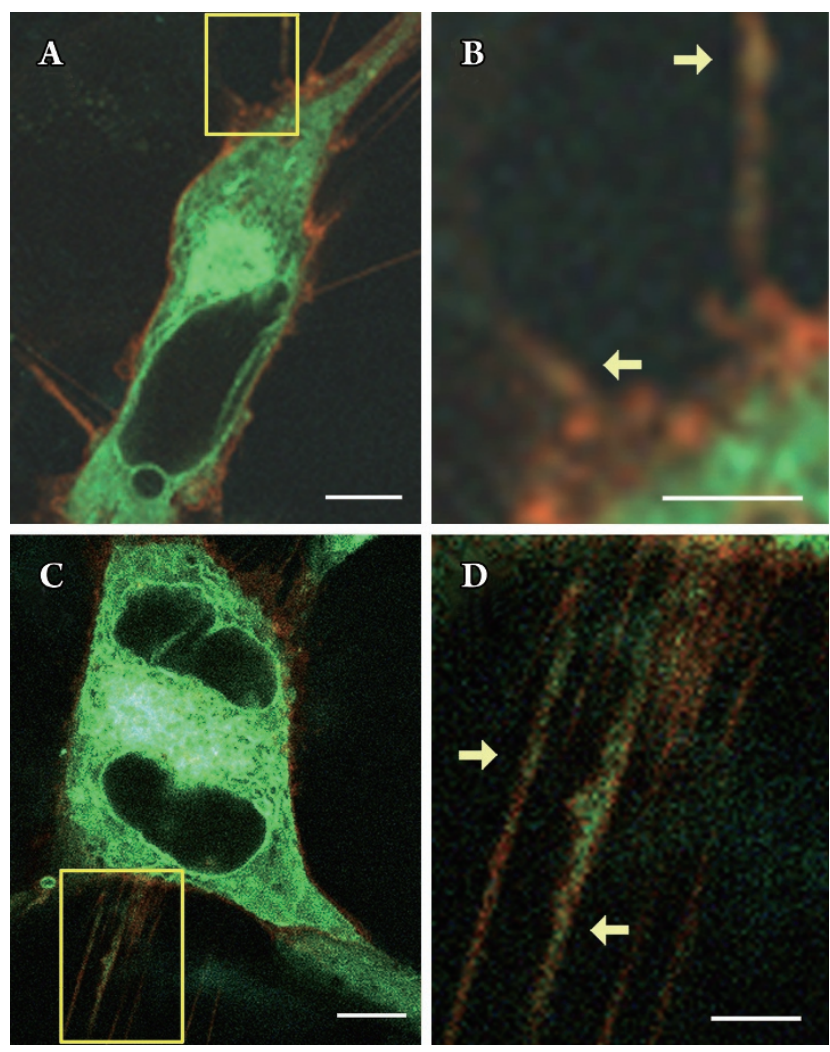

Figure 5. Confocal optical slices of cells expressing $\alpha 7 \mathrm{Y}$. Intracellular localization of $\alpha 7 \mathrm{Y}$ stably expressed in SH-EP1 cells was visualized using confocal microscopy at progressively higher z-positions producing a set of optical slices through the cell. (A) Enlarged and cropped image of representative optical slice of cell expressing $\alpha 7 \mathrm{Y}$ (green) and transiently expressing pmCherry (red) to identify the plasma membrane. (B) Enlarged view of filopodia (boxed area in A) with red fluorescence derived from pmCherry and YFP fluorescence from $\alpha 7 Y$ (arrows). (C) Representative optical slice of cells stably expressing $\alpha 7 \mathrm{Y}$ and transiently expressing pmCherry and the $\alpha 7$ chaperone, hRIC-3 (not fluorescently labeled). (D) Enlarged view of filopodia labeled with pmCherry FP that reveals plasma membrane localization of $\alpha 7 \mathrm{Y}$ (arrows). The scale bars are $5 \mu \mathrm{m}(\mathrm{A}, \mathrm{C})$ and $2 \mu \mathrm{m}$ $(B, D)$. Images were acquired using spectral imaging from $525-680 \mathrm{~nm}$ emission and a $60 \times$ objective.

resentative TIRF image shows a cell with micropodia that contain both pmCherry FP (Figure 6A) and $\alpha 7 \mathrm{Y}$ (Figure $6 \mathrm{~B})$. Several of the dual-labeled micropodia are denoted by arrows. Both images were combined to illustrate colocalization (white areas in Figure 6C).

Spectral imaging acquires the full emission spectrum so that signals beyond the typical filter cut-off range are not attenuated, which maximizes the signal from fluorescent proteins. Linear unmixing, a linear regression fit to the YFP spectrum, removes autofluorescence and overlapping spectra from other fluorophores ${ }^{[9]}$. Optical slices of SH-EP1 cells 

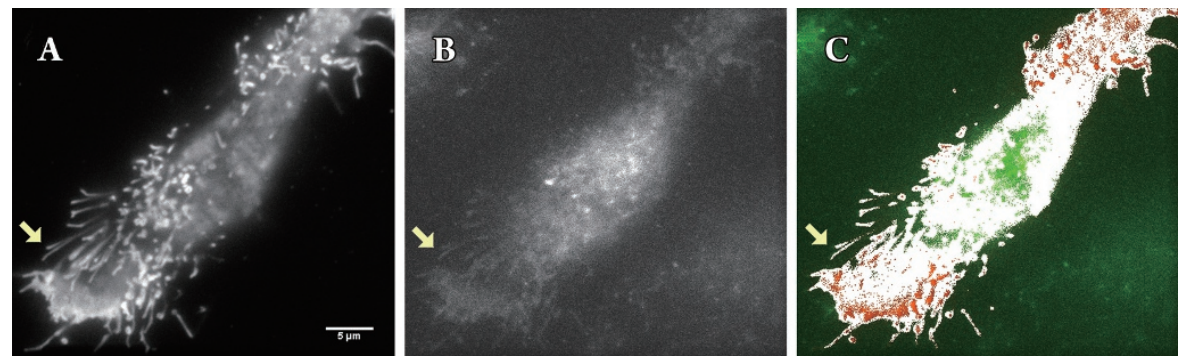

Figure 6. TIRF microscopy images confirm $\alpha 7 \mathrm{Y}$ localization in the plasma membrane. Total internal reflectance fluorescence (TIRF) microscopy was used to assess plasma membrane expression of $\alpha 7 \mathrm{Y}$ in stably transfected SH-EP1 cells that were transiently expressing pmCherry to identify the plasma membrane. Micropodia were used to unambiguously identify regions of plasma membrane. (A) Red FP channel shows pmCherry labeling the cell body and micropodia. (B) YFP channel confirms expression of $\alpha 7 \mathrm{Y}$ in the cell body region and in micropodia. Arrows identify several micropodia that are evident in both channels, implying localization of $\alpha 7 \mathrm{Y}$ in the plasma membrane. (C) Merged image of YFP channel (green) and pmCherry channel (red) shows colocalization (white) in the plasma membrane. Scale bar denotes $5 \mu \mathrm{m}$.

stably expressing $\alpha 7 \mathrm{Y}$ were acquired with the spectral imaging system of a LSCM. A raw spectral image (Figure 7A) provides evidence that the cell was expressing the fluorescent a7Y receptor, but the image reveals relatively little detail regarding its cellular distribution. After linear unmixing, the lattice-like pattern of intracellular YFP distribution becomes apparent (Figure 7B). This pattern was typically observed and resembles the cellular location, size and pattern seen in images of fluorescently-tagged proteins localized to the endoplasmic reticulum $(\mathrm{ER})^{[32]}$. Likewise, the TIRF images showing YFP distribution also have a similar pattern in the cell body region (Figure 7C). A yellow oval is overlaid onto the unmixed confocal image (B) and the TIRF image (C) to illustrate the similarity. SH-EP1 cells exhibit some autofluorescence, especially at higher laser power levels (Figure 7D), thus linear unmixing was useful in removing this noise in the YFP emission range (Figure 7E).

\section{Discussion}

Rationale for placement of YFP in the NAChR $\alpha 7$ subunit C2 loop Three envisioned uses for a fluorescentlytagged $\alpha 7$ subunit are to (1) help define $\alpha 7$ spatial and temporal interactions with fluorescently-labeled chaperone and accessory proteins ${ }^{[29,33]},(2)$ investigate heteromeric assembly with other fluorescently-labeled nicotinic receptor subunits, including determination of subunit stoichiometry ${ }^{[3,10]}$, and (3) examine interactions with other FP-tagged receptors ${ }^{[3]}$. All three involve interaction between proteins. Thus, detection of Förster (or fluorescence) resonance energy transfer (FRET) can be used to show assembly, or interaction between the proteins when both are fluorescently-labeled and the fluorophores are within $10 \mathrm{~nm}$ of each other ${ }^{[9]}$. An excellent position for a FP to meet the proposed uses is in the intracellular domain of the $\alpha 7$ subunit.
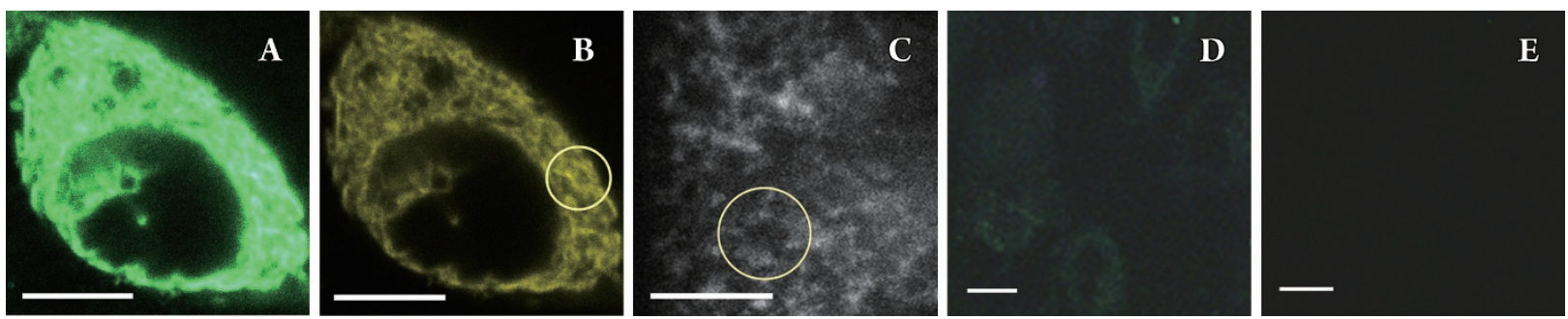

Figure 7. Intracellular localization of $\alpha 7 Y$. (A) LSCM optical slice acquired using spectral imaging through the upper half of a cell stably expressing $\alpha 7 \mathrm{Y}$. The dark oval is the nucleus. (B) YFP image of the same cell after autofluorescence was removed using the Nikon C1 linear unmixing algorithm. $\alpha 7 \mathrm{Y}$ appears in a lattice-like pattern throughout most of the cell, excluding the nucleus. 100x objective $2 \times$ zoom. (C) TIRF image of different cell expressing $\alpha 7 \mathrm{Y}$, cropped to show $\sim 2 \times$ zoom of the cell body up to $100 \mathrm{~nm}$ above the cover slip. A pattern of expression in the cell body region similar to that seen in the confocal image is observed (encircled areas in B-C illustrate the similar pattern). (D) LSCM spectral image of wild type SH-EP1 cells. Laser excitation power was increased three-fold to obtain an image of autofluorescence. (E) Same cell as in D after linear unmixing. The image is black since the autofluorescence is removed by unmixing. Scales bars represent $5 \mu \mathrm{m}(\mathrm{A}-\mathrm{B}, \mathrm{D}-\mathrm{E})$ and $2 \mu \mathrm{m}(\mathrm{C})$. 
Another projected use of an $\alpha 7$ subunit-FP fusion protein is as a target, or 'bait,' for screening large combinatorial libraries of small biomolecules ${ }^{[34-36]}$ to select those molecules with high affinity and specificity toward the subunit's extracellular region. These individual molecules when linked could be used to create small, bivalent probes ${ }^{[37]}$ with further enhanced affinity for the target and could be superior options to the typically low affinity and low specificity antibodies employed in nAChR research ${ }^{[38]}$. An additional, contemplated use for a bivalent probe is for targeted drug delivery ${ }^{[40]}$. Screening of large libraries of compounds likely requires a substantial amount of target ${ }^{[39]}$, as could be provided via a heterologous expression system, such as stably transfected SH-EP1- $\alpha 7 \mathrm{Y}$ cells. Ideally, the probe for $\alpha 7$ would bind to the extracellular domain in its native conformation to facilitate live cell and tissue imaging and drug delivery. This is another reason for placing the FP in the intracellular loop, where it would not disrupt the extracellular region.

Design of the a7 subunit-FP fusion protein One strategy to insert a fluorescent protein into the $\mathrm{C} 2$, large cytoplasmic loop of the $\mathrm{nAChR} \alpha 7$ subunit is to delete a portion of the loop and replace it with the FP. This could potentially avoid some of the problems caused by introducing a sizeable $27-\mathrm{kDa}$ protein into a region two-thirds of that size. In a study of the role of residues in the $\mathrm{C} 2$, large cytoplasmic loop, Valor and colleagues ${ }^{[7]}$ systematically deleted portions of the C2 loop of the rat $\alpha 7$ subunit and found residues critical for expression and function. Moreover, they discovered that a large region between residues 339-432 could be deleted without changing surface expression or function. Conversely, some deletions abolished or severely reduced expression and function, such as removing residues near the transmembrane domains, while others dramatically increased function, such as deleting residues 326-432 and replacing them with a 7-residue sequence for a restriction enzyme. This latter deletion and substitution resulted in a nearly $400 \%$ increase in function. However, when Valor et al replaced the deleted segment with GFP, the fluorescent receptor had roughly $70 \%$ fewer surface binding sites for I-Bgt than the wild type receptor and an even greater reduction in functional responsiveness.

Alternatively, Nashmi and colleagues ${ }^{[9]}$ successfully inserted a FP into the C2 loop of either the $\alpha 4$ and $\beta 2$ $\mathrm{nAChR}$ subunits without removing any of the residues, thus preserving trafficking sites and only disrupting one of several phosphorylation sites in the $\alpha 4$ subunit. Other fusions of FP into $\mathrm{C} 2$ loops of $\mathrm{nAChR} \alpha 6$ or $\beta 3$ subunits $^{[10]}$ or muscle-type $\mathrm{nAChR} \varepsilon$ or $\gamma$ subunits ${ }^{[41]}$ confirm that by avoiding phosphorylation and trafficking sites, fusion proteins produce receptors with distribution and/or function similar to wild type receptors. The current studies demonstrate that similar insertion of YFP into the $\alpha 7$ subunit C2 domain (Figure 1) produces $\alpha 7 \mathrm{Y}$ nAChRs with properties like those of receptors made from wild-type subunits.

Electrophysiological studies show that $\alpha 7 \mathrm{Y}$ nAChRs and $\alpha 7 \mathrm{nAChRs}$ have comparable function nAChRs composed of either wild type $\alpha 7$ or $\alpha 7 Y$ have similar and relatively low peak whole-cell current responses to choline, a full agonist of $\alpha 7 \mathrm{nAChR}$. Responses to choline increased twofold for both the wild type and fluorescent $\alpha 7 \mathrm{nAChR}$ when co-expressed with hRIC-3. These were remarkably similar results, considering that cells were stably transfected with $\alpha 7 \mathrm{Y}$ or transiently transfected with $\alpha 7$.

Prior work has demonstrated that hRIC-3 promotes a7 nAChR expression ${ }^{[29,42]}$; thus, the increase in current after transfection was not surprising. Notably, since responses to choline increased by the same factor for both types of receptors, the results imply that interaction with hRIC-3 was not abolished by insertion of YFP downstream of the putative hRIC- 3 binding site in the $\alpha 7$ subunit C2 loop ${ }^{[29]}$. Additionally, both receptors had similar $\mathrm{EC}_{50}$ values for functional activation by choline and $\mathrm{IC}_{50}$ values for functional inhibition by MLA, further demonstrating that $\alpha 7 \mathrm{Y}$ nAChRs and $\alpha 7$ nAChRs have comparable functional features. In summary, the electrophysiological data suggest that the YFP fusion did not adversely affect receptor function or interaction with hRIC-3.

Although the simplest explanation of the very similar levels of cell surface radiotoxin binding and the nearly identical levels of function in cells expressing $\alpha 7 \mathrm{Y}$ or $\alpha 7$ proteins and receptors is that they were expressed at comparable levels, this conclusion is tentative because of the different techniques of transfection used and because comparisons are complicated between transiently or stably transfected cells. Thus, it is possible that FP insertion did affect polypeptide folding, assembly, trafficking and function. For example, it is possible that the 20-residue distance between the FP fusion and the putative hRIC-3 binding site was too short to avoid some reduction in the efficiency of hRIC-3-enhanced trafficking and function. However, whether hRIC-3 was coexpressed with $\alpha 7 \mathrm{Y}$ or with $\alpha 7$, whole cell current response amplitudes doubled. Although FP insertion could have differentially affected surface expression of one or the other subunit construct but with a compensating alteration in function, we favor the interpretation that that there is similar expression, function and interaction with hRIC-3 for $\alpha 7$ and for $\alpha 7 Y$.

Radioligand binding assays confirm that $\alpha 7 \mathrm{Y}$ nAChRs 
can bind I-Bgt Although studies done in the absence of the putative chaperone were negative, additional studies in which cells also expressed hRIC-3, confirmed that $\alpha 7 \mathrm{Y}$ nAChRs, as well as $\alpha 7 \mathrm{nAChRs,}$, are able to specifically bind I-Bgt. Both electrophysiological and TIRF microscopy results revealed surface expression of $\alpha 7 \mathrm{nAChRs}$ and $\alpha 7 \mathrm{Y} \mathrm{nAChRs}$ in the absence of additional hRIC-3, and electrophysiology revealed an increase in expression in cells co-transfected with hric-3 cDNA. Thus, the sensitivity of I-Bgt binding assays simply may be too low to detect surface receptors unless they already are expressed abundantly or unless their levels were increased upon co-expression with hRIC-3.

Confocal microscopy shows intracellular expression of $\boldsymbol{\alpha} 7 \mathbf{Y}$ Optical slices of $\alpha 7 Y$ cells captured using LSCM revealed an extensive lattice-like pattern of YFP fluorescence throughout most of the cell (Figures 4 and 6). This large area inside the cell likely corresponds to subunits being synthesized and assembled in the ER, because the intracellular distribution and pattern of YFP intensity matches the lattice-like pattern observed when cells are stained for ER membrane proteins ${ }^{[10,32]}$. In contrast, confocal images confirmed that the pmCherry was almost completely localized to the plasma membrane, and it was not observed intracellularly. Relying solely on confocal images, it was difficult to ascertain the relative amount of $\alpha 7 \mathrm{Y}$ in the plasma membrane as identified by localization with pmCherry. However, cells had some regions in which both appeared co-localized, most often in the filopodia extending outward from the cell body (Figure 4B and 4D). Qualitatively, co-transfection with hRIC-3 did not appear to increase the amount of $\alpha 7 \mathrm{Y}$ at the membrane based simply on confocal microscopic examination. The question of whether or not hRIC-3 increased the amount of $\alpha 7 \mathrm{Y}$ in internal pools was not systematically addressed in this study due to the variability in intensity of YFP fluorescence between individual SH-EP1- $\alpha 7$ Y cells. Nevertheless, whether or not in the presence of hRIC-3, there was extensive intracellular distribution of $\alpha 7 \mathrm{Y}$, excluding the nucleus. This is consistent with observations in other studies of heterologously expressed nicotinic receptor subunits and assemblies $\left(\alpha 3 \beta 4^{[12]}, \mathrm{a} 6^{*}\right.$, and $\mathrm{b} 3^{*[10]}, \alpha 4 \beta 2^{[43]}$, and $\alpha 7^{[8]}$ ) that reveal a predominantly intracellular localization. Perhaps this also occurs naturally, and it might not be a surprise given the large mass ratio of intracellular membrane pool mass to plasma membrane mass.

TIRF microscopy reveals surface expression of $\alpha 7 Y$ Whereas LSCM was able to confirm expression of $\alpha 7 Y$ and that a large portion was localized to intracellular compartments, it was not able to adequately resolve distribution at the plasma membrane partly due to the natural, curved contour of the cells and due to limitations on the minimal thickness of optical slices. Hence, it is likely that features inside the cell can be imaged in the same optical slice as the membrane ${ }^{[44]}$. Fortunately, SH-EP1 cells come into some contact with the coverslip, especially through micropodia, which do not contain $\mathrm{ER}^{[32]}$. TIRF microscopy was used to visualize micropodia in a region within about $100 \mathrm{~nm}$ of the cover slip. Micropodia have served in prior studies as regions of plasma membrane localization ${ }^{[10,12]}$. This ability in concert with the membrane marker, pmCherry, provided an opportunity to unambiguously identify some regions of the plasma membrane. Additionally, TIRF microscopy allowed for detection of lower levels of fluorescence than can be detected in confocal microscope images. TIRF microscopy also dramatically reduced out-of-focus light ${ }^{[45]}$, enabling better discrimination of fine features, such as the distribution of small amounts of $\alpha 7$ subunit-fused YFP detected in micropodia. In fact there were a number of cells that had $\alpha 7 \mathrm{Y}$ in micropodia and in distal regions of filopodia, indicating that a small proportion of $\alpha 7 \mathrm{Y}$ (presumably in closed, pentameric assemblies as $\alpha 7 \mathrm{Y} \mathrm{nAChRs}$ ) is, indeed, expressed at the cell surface (Figure 6B).

Using stably transfected cells, all expressed some level of $\alpha 7 Y$, although YFP fluorescence intensity varied from cell to cell. However, only about $15 \%$ of the cells inspected had apparent micropodial and distal filopodial localization. This apparent absence of membrane-localized YFP in the majority of cells was an unexpected result. One possible reason for the low detection level was that a shorter, sub-optimal wavelength was used to excite YFP to avoid directly exciting the pmCherry FP. Another is that filopodia growing over edges of neighboring cells would not be visible using TIRF microscopy. Certainly, $\alpha 7$ has very low levels of surface expression, with as little as $0.3 \%$ being expressed at the surface ${ }^{[8]}$; thus, very low levels of expression may have gone undetected. As for receptors on the cell body, the TIRF method was not able to discriminate between the YFP signal from presumably low levels of surface-expressed $\alpha 7 \mathrm{Y}$ and the relatively bright YFP signal emanating from $\alpha 7 \mathrm{Y}$ subunits in intracellular compartments located near the plasma membrane (Figure 7C).

Utility of fluorescent $\boldsymbol{\alpha} 7$ subunits Fluorescently tagged nAChR subunits have some attractive properties. They can overcome problems associated with other probes, such as antibodies, which often do not discriminate well between subunits with high homology ${ }^{[38,46]}$. Antibodies also are not always useful for live cell and tissue imaging, especially in neural synapses ${ }^{[47]}$. Moreover, a fluorescent protein tag obviates the need for labeling procedures that can damage the protein and/or the cells or tissues being studied. Addition- 
ally, transgenes containing tagged subunits may be incorporated into viral vectors and used in subunit knockout animals to selectively reintroduce tagged subunits into a region of interest, thereby allowing a broad range of techniques to be applied to define subunit and receptor localization and function $^{[48]}$. Potential drawbacks to fluorescent protein fusion do exist and have been enumerated by others ${ }^{[4,5,41]}$. Briefly, they include alterations in coassembly, trafficking and function.

In testing $\mathrm{nAChR}$ composed of the fluorescently tagged $\alpha 7$ subunit, $\alpha 7 \mathrm{Y}$, for expression and function, it was shown that they had nearly identical agonist and antagonist responses to choline and MLA, respectively, when compared to wild type mouse $\alpha 7 \mathrm{nAChRs}$. It was also found that $\alpha 7 \mathrm{Y}$ protein and perhaps also $\mathrm{nAChRs}$ exist primarily in intracellular pools and have relatively low surface expression, which is consistent with published reports for $\alpha 7$ and other nAChRs ${ }^{[8,10,12,43]}$. Additionally, I-Bgt binding assays demonstrated that Bgt binds $\alpha 7 \mathrm{Y}$ nAChRs as well as $\alpha 7 \mathrm{nAChRs}$. Taken together, all the lines of evidence show that the YFP fusion in the large intracellular loop, between M3-M4, preserves the ability of $\alpha 7 \mathrm{Y}$ to assemble into receptors that function in the same manner as wild type $\alpha 7 \mathrm{nAChR}$. Accordingly, $\alpha 7 \mathrm{Y}$ is likely to prove extremely useful in further studies of $\alpha 7 \mathrm{nAChR}$ trafficking, associations with fluorescently tagged accessory and chaperone proteins, visualizing localization in live neurons and the effects of drugs on upregulation or downregulation of the receptor. Expanding on the last point, $\alpha 7 \mathrm{Y}$ cell lines could be used to signal changes in a7 $\mathrm{nAChR}$ expression levels in cell-based high throughput screening assays. It may also find use as a 'bait' for screening combinatorial libraries of potential ligands. $\alpha 7 \mathrm{Y}$ may even help settle the questions about heteromeric assembly with other nAChR subunits and their stoichiometry ${ }^{[9,10,49,50]}$. Therefore, $\alpha 7 \mathrm{Y}$ should be a useful addition to the existing set of fluorescently tagged mouse $\mathrm{nAChR}$ subunits.

\section{Acknowledgements}

We wish to thank Dr Henry LESTER, California Institute of Technology, for the generous use of his facilities for performing confocal and TIRF studies. We also thank Dr Rigo PANTOJA and Dr Rahul SRINIVASAN for instruction and assistance using the TIRF and confocal microscope systems in Dr Lester's lab. We also gratefully acknowledge Dr Sean MEGASON, California Institute of Technology for the kind gift of the pCS2-mCherry construct; Dr Henry LESTER and Dr Raad NASHMI (formerly of the Lester lab and now at the University of Vancouver) for their gift of the a4-HA-YFP
nAChR construct; and Dr Millet TREININ of Hebrew University for the gift of the hRIC-3 construct through Dr William GREEN of the University of Chicago.

This work was supported by a National Institutes of Health Grant DA015389, the Barrow Neurological Foundation, and the Biodesign Institute at Arizona State University. TA MURRAY was supported by a National Science Foundation Graduate Research Fellowship and a Catholic Healthcare West SEED grant.

\section{Author contribution}

Teresa A MURRAY designed the research, cloned the mouse $\alpha 7$ gene, created the $\alpha 7 \mathrm{Y}$ fusion protein, performed microscopy and radioligand binding experiments, and wrote the paper, with assistance as noted. Qiang LIU performed and summarized all electrophysiological experiments, and Jie WU provided guidance and edited the manuscript with respect to electrophysiology experiments. Paul WHITEAKER co-designed and co-performed radioligand binding assays and provided guidance for presenting data. Ronald LUKAS and Paul WHITEAKER assisted in writing the paper.

\section{References}

1 Chalfie M, Tu Y, Euskirchen G, Ward WW, Prasher DC. Green fluorescent protein as a marker for gene expression. Science 1994; 263: 802-5.

2 Tsien RY. The green fluorescent protein. Ann Rev Bioch 1998; 67: 509-44.

3 Khakh BS, Fisher JA, Nashmi R, Bowser DN, Lester HA. An angstrom scale interaction between plasma membrane ATP-gated $\mathrm{P} 2 \mathrm{X}_{2}$ and $\alpha_{4} \beta_{2}$ nicotinic channels measured with fluorescence resonance energy transfer and total internal reflection fluorescence microscopy. J Neurosci 2005; 25: 6911-20.

4 Fucile S, Palma E, Martínez-Torres A, Miledi R, Eusebi F. The single-channel properties of human acetylcholine $\alpha 7$ receptors are altered by fusing $\alpha 7$ to the green fluorescent protein. Proc Natl Acad Sci USA 2002; 99: 3956-61.

5 Palma E, Mileo AM, Martínez-Torres A, Eusebi F, Miledi R. Some properties of human neuronal $\alpha 7$ nicotinic acetylcholine receptors fused to the green fluorescent protein. Proc Natl Acad Sci USA 2002; 99: 3950-5.

6 Prasher DC, Eckenrode VK, Ward WW, Prendergast FG, Cormier MJ. Primary structure of the Aequorea victoria green-fluorescent protein. Gene 1992; 111: 229-33.

7 Valor LM, Mulet J, Sala F, Sala S, Ballesta JJ, Criado M. Role of the large cytoplasmic loop of the alpha 7 neuronal nicotinic acetylcholine receptor subunit in receptor expression and function. Biochem 2002; 417931-8.

8 Toulmé E, Soto F, Garret M, Boué-Grabot E. Functional properties of internalization-deficient $\mathrm{P}_{2} \mathrm{X}_{4}$ receptors reveal a novel 
mechanism of ligand-gated channel facilitation by ivermectin. Mol Pharmacol 2005; 69: 576-87.

9 Nashmi R, Dickinson ME, McKinney S, Jareb M, Labarca C, Fraser $\mathrm{SE}$, et al. Assembly of $\alpha 4 \beta 2$ nicotinic acetylcholine receptors assessed with functional fluorescently labeled subunits: effects of localization, trafficking, and nicotine-induced upregulation in clonal mammalian cells and in cultured midbrain neurons. J Neurosci 2003; 23: 11554-67.

10 Drenan M, Nashmi R, Imoukhuede P, Just H, McKinney S, Lester HA. Subcellular trafficking, pentameric assembly, and subunit stoichiometry of neuronal nicotinic acetylcholine receptors containing fluorescently labeled $\alpha 6$ and $\alpha 3$ subunits. Mol Pharmacol 2008; 73: 27-41.

$11 \mathrm{Xu} \mathrm{J}$, Zhu Y, Heinemann SF. Identification of sequence motifs that target neuronal nicotinic receptors to dendrites and axons. J Neurosci 2006; 26: 978 - 93.

12 Graihle R, de Carvalho LP, Pass Y, Le Poupon C, Soudant M, Bregestovski $\mathrm{P}$, et al. Distinct subcellular targeting of fluorescent nicotinic $\alpha 4 \beta 3$ and serotoninergic 5-HT3A receptors in hippocampal neurons. Eur J Neurosci 2004; 19: 855-62.

13 Slimko EM, Lester HA. Codon optimization of Caenorhabditis elegans $\mathrm{GluCl}$ ion channel genes for mammalian cells dramatically improves expression levels. J Neurosci Methods 2003; 124: 75-81.

14 Ilegems E, Pick HM, Deluz C, Kellenberger S, Vogel H. Noninvasive imaging of 5-HT3 receptor trafficking in live cells: from biosynthesis to endocytosis. J Biol Chem 2004; 279: 53346-52.

15 Pantoja R, Rodriguez EA, Dibas MI, Dougherty DA, Lester HA. Single-molecule imaging of a fluorescent unnatural amino acid incorporated into nicotinic receptors. Biophysical J 2009; 96: 226-37.

16 Harkness PC, Millar NS. Changes in conformation and subcellular distribution of $\alpha 4 \beta 2$ nicotinic acetylcholine receptors revealed by chronic nicotine treatment and expression of subunit chimeras. J Neurosci 2002; 22: 10172-81.

17 Zhang J, Berg DK. Reversible inhibition of $\mathrm{GABA}_{\mathrm{A}}$ receptors by $\alpha 7$-containing nicotinic receptors on the vertebrate postsynaptic neurons. J Physiol 2007; 579: 753-63.

18 Dajas-Bailador FA, Soliakov L, Wonnacott S. Nicotine activates the extracellular signal-regulated kinase $1 / 2$ via the alpha7 nicotinic acetylcholine receptor and protein kinase $\mathrm{A}$, in SH-SY5Y cells and hippocampal neurones. J Neurochem 2002; 80: 520-30.

19 Song C, Murray TA, Kimura R, Wakui M, Ellsworth K, Javedan SP, et al. Role of alpha7-nicotinic acetylcholine receptors in tetanic stimulation-induced gamma oscillations in rat hippocampal slices. Neuropharm 2005; 48: 869-80.

20 Picciotto MR, Caldarone BJ, King SL, Zachariou V. Nicotinic receptors in the brain: links between molecular biology and behavior. Neuropsychopharmacology 2000; 22: 451-65.

21 Lukas RJ, Bencherif M. Recent developments in nicotinic acetylcholine receptor biology. In: Biological and biophysical aspects of ligand-gated ion channel receptor superfamilies. Arias $\mathrm{H}$, editor. Kerala, India: Research Signpost; 2006. p27-59.

22 Ross RA, Spengler BA, Biedler JL. Coordinate morphological and biochemical interconversion of human neuroblastoma cells. J Natl Cancer Inst 1983; 71: 741-7.

23 Walton JD, Kattan DR, Thomas SK, Spengler BA, Guo H, Biedler $\mathrm{JL}$, et al. Characteristics of stem cells from human neuroblastoma cell lines and in tumors. Neoplasia 2004; 6: 838-45.
24 Peng JH, Lucero L, Fryer J, Herl J, Leonard SS, Lukas RJ. Inducible, heterologous expression of human alpha7-nicotinic acetylcholine receptors in a native nicotinic receptor-null human clonal line. Brain Res 1999; 825:172-9.

25 Halevi S, Yassin L, Eshel M, Sala F, Sala S, Criado M, et al. Conservation within the RIC-3 gene family: effectors of mammalian nicotinic acetylcholine receptor expression. J Biol Chem 2003; 278: 34411-7.

26 Trichas G, Begbie J, Srinivas S. Use of the viral 2A peptide for bicistronic expression in transgenic mice. BMC Biology 2008; 6: 40.

27 Wu J, Kuo YP, George AA, Xu L, Hu J, Lukas RJ. beta-Amyloid directly inhibits human alpha4beta2-nicotinic acetylcholine receptors heterologously expressed in human SH-EP1 cells. J Biol Chem 2004; 279:37842-51.

28 Fryer JD, Lukas RJ. Noncompetitive functional inhibition at diverse, human nicotinic acetylcholine receptor subtypes by bupropion, phencyclidine, and ibogaine. J Pharmacol Exp Ther 1999; 288: 88-92.

29 Castillo M, Mulet J, Gutierrez LM, Ortiz JA, Castelan F, Gerber S, et al. Dual role of the RIC-3 protein in trafficking serotonin and nicotinic receptors. J Biol Chem 2005; 280: 27062-8.

30 Blom N, Gammeltoft S, Brunak S. Sequence- and structure-based prediction of eukaryotic protein phosphorylation sites. J Mol Biol 1999; 294:1351-62.

31 Quick MW \& Lester RA. Desensitization of neuronal nicotinic receptors. J Neurobiol 2002; 53: 457-78.

32 Alberts B, Johnson A, Lewis J, Raff M, Roberts K, Walter P. Molecular Biology of the Cell. 4th Ed. New York: Garland Science. 2002

33 Miwa JM, Stevens TR, King SL, Caldarone BJ, Ibanez-Tallon I, Xiao C, et al. The prototoxin lynx1 acts on nicotinic acetylcholine receptors to balance neuronal activity and survival in vivo. Neuron 2006; 5: 587-600.

34 Tuerk C, Gold L. Systematic evolution of ligands by exponential enrichment: RNA ligands to bacteriophage T4 DNA polymerase. Science 1990; 3: 505-10.

35 McGuire MJ, Samli KN, Chang YC, Brown KC. Novel ligands for cancer diagnosis: Selection of peptide ligands for identification and isolation of B-cell lymphomas. Exper Hematol 2006; 34: 443-52.

36 Wilson DS, Keefe AD, Szostak JW. The use of mRNA display to select high-affinity protein-binding peptides. Proc Natl Acad Sci USA 2001; 98: 3750-5.

37 Ni F. Bivalent Bridged Polypeptides for Tumour-targeting, Imaging and Controllable Therapeutic Intervention [homepage on the Internet]. Biotechnology Research Institute, Canada. [Updated 01-25-2007; cited 2-1-2009] Available at: http://www.irb-bri.cnrcnrc.gc.ca/rd/health/nmr/2007activities_e.html\#networks.

38 Moser N, Mechawar N, Jones I, Gochberg-Sarver A, Orr-Urtreger A, Plomann $\mathrm{M}$, et al. Evaluating the suitability of nicotinic acetylcholine receptor antibodies for standard immunodetection procedures. J Neurochem 2007; 102: 479-92.

39 Eisenstein M. 'Chain gang' delivers for hard labor. Nat Meth 2006; 3: 753-62.

40 George S, O'Dowd BF, Lee SP. G-protein-coupled receptor oligomerization and its potential for drug discovery. Nat Rev Drug Discov 2002; 1:808-20.

41 Gensler S, Sander A, Korngreen A, Traina G, Giese G, Witzemann 
V. Assembly and clustering of acetylcholine receptors containing GFP-tagged $\varepsilon$ or $\gamma$ subunits: Selective targeting to the neuromuscular junction in vivo. Eur J Biochem 2001; 268: 2209-17.

42 Williams ME, Burton B, Urrutia A, Shcherbatko A, ChavezNoriega LE, Cohen CJ, et al. Ric-3 promotes functional expression of the nicotinic acetylcholine receptor subunit $\alpha 7$ in mammalian cells. J Biol Chem 2005; 280: 1257-63.

43 Whiteaker P, Sharples CG, Wonnacott S. Agonist-induced upregulation of alpha4beta2 nicotinic acetylcholine receptors in M10 cells: pharmacological and spatial definition. Mol Pharmacol 1998; 53: 950-62.

44 North AJ. Seeing is believing? A beginners' guide to practical pitfalls in image acquisition. J Cell Biol 2006; 172: 9-18.

45 George N. TIRF microscopy: the evanescent wave of the future. Amer Lab 2004; 8: 26-68.

46 Herber DL, Severance EG, Cuevas J, Morgan D, Gordon MN. Biochemical and histochemical evidence of nonspecific binding of alpha7 nAChR antibodies to mouse brain tissue. J Histochem Cytochem 2004; 52:1367-76.

47 Dahan M, Lévi S, Luccardini C, Rostaing P, Riveau B, Triller A. Diffusion dynamics of glycine receptors revealed by single- quantum dot tracking. Science 2003; 302: 442-5.

48 Pons S, Fattore L, Cossu G, Tolu S, Porcu E, McIntosh JM, et al. Crucial role of alpha4 and alpha6 nicotinic acetylcholine receptor subunits from ventral tegmental area in systemic nicotine selfadministration. J Neurosci 2008; 28:12318-27.

49 Azam L, Winzer-Serhan U, Leslie FM. Co-expression of $\alpha 7$ and $\beta 2$ nicotinic acetylcholine receptor subunit mRNAS within rat brain cholinergic neurons. Neurosci 2003; 119: 965-77,

50 Khiroug SS, Harkness PC, Lamb PW, Sudweeks SN, Khiroug L, Millar NS, et al. Rat nicotinic Ach receptor $\alpha 7$ and $\beta 2$ subunits co-assemble to form functional heteromeric nicotinic receptor channels. J Physiol 2002; 540.2: 425-34.

51 Peng JH, Fryer JD, Hurst RS, Schroeder KM, George AA, Morrissy $S$, et al. High-affinity epibatidine binding of functional, human $\alpha 7$-nicotinic acetylcholine receptors stably and heterologously expressed de novo in human SH-EP1 cells. J Pharm Exp Ther 2005; 313: 24-35.

52 Laummonerie C, Mutterer J. Colocalization Finder Version 1.2 plug-in for Image J image analysis software. Available online http://rsb.info.nih.gov/ij/plugins/colocalization-finder.html. 2006 